Review

\title{
For the Evaluation of Pacific Island Athletes, an ECG and Echocardiography Are Highly Recommended
}

\author{
Jean-Claude Chatard ${ }^{1,2}$ iD
}

1 Inter-University Laboratory of Human Movement Science, Faculty of Medicine Jacques Lisfranc, University Lyon-Saint-Etienne, CEDEX 2, 42023 Saint-Etienne, France; chatard@univ-st-etienne.fr; Tel.: +33-6-64-51-60-17

2 Service de Physiologie Clinique et de l'Exercice, CHU de Saint-Etienne, CEDEX 2, 42055 Saint-Etienne, France

check for updates

Citation: Chatard, J.-C. For the Evaluation of Pacific Island Athletes, an ECG and Echocardiography Are Highly Recommended. Hearts 2021, 2, 270-277. https://doi.org/10.3390/ hearts2020021

Academic Editor:

Matthias Thielmann

Received: 13 April 2021

Accepted: 12 May 2021

Published: 14 May 2021

Publisher's Note: MDPI stays neutral with regard to jurisdictional claims in published maps and institutional affiliations.

Copyright: (c) 2021 by the author. Licensee MDPI, Basel, Switzerland. This article is an open access article distributed under the terms and conditions of the Creative Commons Attribution (CC BY) license (https:// creativecommons.org/licenses/by/ $4.0 /)$.

\begin{abstract}
Physical exercise increases the relative risk of sudden cardiac death (SCD) in athletes when compared to a non-sporting population. Pre-participation evaluation (PPE) of athletes is thus of major importance. For Pacific Island athletes, medical guidelines recommend an echocardiography to complement a PPE including personal and family history, a physical examination and a resting twelve-lead electrocardiogram (ECG). Indeed, silent rheumatoid heart diseases found in up to 7.6\% of adolescents give rise to severe valve lesions, which are the main causes of SCD in Pacific Island athletes. This short review examines the incidence rate of SCD in Pacific Island athletes and indicates how a questionnaire, physical examination, ECG and echocardiography can prevent it.
\end{abstract}

Keywords: Melanesian; Polynesian; Black athlete; cardiomyopathy; pre-participation evaluation; athlete screening

\section{Introduction}

In Pacific Island athletes, the estimated incidence rate of SCD is 3.9/100,000 athletes versus 1-2/100,000 athletes /year in Western countries or 34.2/100,000 athletes in specific American sports and ethnicities like Afro-Caribbean basketball players [1].

The aim of a pre-participation cardiovascular evaluation (PPE) is to detect the CV diseases that have a risk of SCD. As about $80 \%$ of these diseases are asymptomatic [2], a resting twelve-lead electrocardiogram (ECG) is recommended [3].

In Pacific Island athletes, echocardiography is also recommended. Indeed, school surveys reported a high prevalence of silent rheumatic heart disease (RHD) reaching a level of $7.6 \%$ in asymptomatic children. $\mathrm{RDH}$ gives rise to severe valve lesions related to acute rheumatic fever (ARF) and are the major causes of SCD.

This short review will examine the incidence rate of SCD in Pacific Island athletes and how a questionnaire, physical examination, ECG and echocardiography can prevent it.

\section{Incidence Rate of Sudden Cardiac Death}

In Pacific Islands athletes, SCD was studied only in New Caledonia, an island located in the South Pacific at $1200 \mathrm{~km}$ east of Australia and $1500 \mathrm{~km}$ from New Zealand [4]. During a 7-year follow up, the incidence rate was estimated to be 3.9 cases of SCD per 100,000 athletes, age range 15-20 years, and concerned a majority of Melanesian athletes who are genetically Black people (Table 1 ). These values are $2-3$ fold higher than those in western countries but remain far fewer than the 34 cases of SCD/100,000 athletes found in Afro-Caribbean basketball players [1]. 
Table 1. Sudden cardiac death (SCD) in athletes and non-athletes registered between 2012 and 2014 in the New Caledonian population 10-40 age group: Poly = Polynesian, $\mathrm{Mel}=$ Melanesian, HCM = hypertrophic cardiomyopathy, WPW = WolffParkinson-White, RHD = rheumatic heart disease, UR = un resuscitated after electric shock, * resuscitation after an SC arrest and an electric shock, ${ }^{* *}$ estimation.

\begin{tabular}{|c|c|c|c|c|c|c|c|c|}
\hline Subjects & Category & $n$ & SCD & Age & Sex & Sports & Ethnicity & Cause \\
\hline \multirow{7}{*}{$\begin{array}{l}\text { Athletes } \\
\text { (A) }\end{array}$} & Elite and Interregional & 362 & 1 & 18 & $\mathrm{~F}$ & Shot put & Polynesian & Prolonged QT suspicion \\
\hline & Elite school of sports & 431 & 0 & & $\mathrm{M}$ & & & \\
\hline & Other registered athletes & 42,655 & 1 & 17 & $\mathrm{M}$ & Badminton & Métis & Ventricular rhythm issue * \\
\hline & & & 1 & 18 & $\mathrm{M}$ & Football & Melanesian & $\mathrm{HCM}$ \\
\hline & Not registered athletes ** & 7800 & 3 & $\begin{array}{l}16 \\
15 \\
20 \\
\end{array}$ & $\begin{array}{l}\mathrm{M} \\
\mathrm{M} \\
\mathrm{M}\end{array}$ & $\begin{array}{l}\text { Basketball } \\
\text { Badminton } \\
\text { Golf } \\
\end{array}$ & $\begin{array}{l}\text { Melanesian } \\
\text { Unknown } \\
\text { Polynesian } \\
\end{array}$ & $\begin{array}{c}\text { Ventricular rhythm issue, } \\
\text { Unknown, UR } \\
\text { Unknown }\end{array}$ \\
\hline & Army ** & 1000 & 1 & 18 & M & Running & Melanesian & $\begin{array}{l}\text { Ventricular rhythm issue, possible } \\
\text { HCM previous inverted T waves }\end{array}$ \\
\hline & Total 4.4/100,000/year & 53,041 & 7 & & & & & \\
\hline \multirow{7}{*}{$\begin{array}{l}\text { Non } \\
\text { Athletes } \\
\text { (B) }\end{array}$} & & & 8 & - & - & - & Melanesian & Consequence of RHD \\
\hline & & & 6 & - & - & - & Melanesian & Aneurysms \\
\hline & & & 5 & - & - & - & Melanesian & Massive heart infarction \\
\hline & & & 2 & - & - & - & Melanesian & Pulmonary embolism \\
\hline & & & 1 & - & - & - & Melanesian & Mellitus coma \\
\hline & & & 10 & - & - & - & Melanesian & Unknown \\
\hline & Total 18.3/100,000/year & 58,267 & 32 & - & - & - & - & - \\
\hline$(\mathrm{A})+(\mathrm{B})$ & Total 11.7/100,000/year & 111,308 & 39 & - & - & - & - & - \\
\hline
\end{tabular}

\section{Differences between Countries}

In Germany, the incidence rate was 0.1 to 0.2 cases of SCD/100,000 athletes [5], vs. 0.3 to $0.6 \mathrm{SCD} / 100,000$ athletes in the USA [6], vs. 1/100,000 in France [7], 1.2/100,000 in Denmark [8], 2.1/100,000 in the Veneto region of Italy [9], and 3.9/100,000 in New Caledonia (Table 2) [4].

Table 2. Incidence rate of sudden cardiac death related to exercise in different countries: comparison between male and female, White and Black athletes, and sports.

\begin{tabular}{|c|c|c|c|c|c|c|}
\hline Authors & Country & $\begin{array}{l}\text { Studied } \\
\text { Period }\end{array}$ & $\begin{array}{l}\text { Age } \\
\text { Years }\end{array}$ & Category & $\begin{array}{c}\text { Total } \\
\text { Million }\end{array}$ & $\begin{array}{l}\text { Incidence Rate } \\
/ 100,000\end{array}$ \\
\hline \multirow{2}{*}{ Chatard et al., 2019 [4] } & \multirow{2}{*}{$\begin{array}{l}\text { New } \\
\text { Caledonia }\end{array}$} & 2011-2017 & $10-40$ & $\begin{array}{c}\text { Elite athletes } \\
\text { Melanesian+Polynesian+Wallisian+White }\end{array}$ & & 3.9 \\
\hline & & 2012-2014 & $10-40$ & $\begin{array}{l}\text { Registered and non-registered athletes } \\
\text { Melanesian+Polynesian+Wallisian+White }\end{array}$ & 0.11 & 11.7 \\
\hline \multirow{12}{*}{ Harmon et al., 2011 [1] } & \multirow{12}{*}{ USA } & \multirow{12}{*}{ 2004-2008 } & \multirow{12}{*}{$15-24$} & Black + White & 1.9 & 2.3 \\
\hline & & & & Black & 0.3 & 5.7 \\
\hline & & & & White & 1.6 & 1.7 \\
\hline & & & & Black male & & 7.7 \\
\hline & & & & Basketball & & 8.8 \\
\hline & & & & Male & & 14.3 \\
\hline & & & & Female & & 2.6 \\
\hline & & & & Division I & 0.8 & 34.3 \\
\hline & & & & Division I Black male & & 32 \\
\hline & & & & Swimming & - & 4.3 \\
\hline & & & & Football & - & 2.6 \\
\hline & & & & Cross country & - & 2.4 \\
\hline Maron et al., 2016 [6] & USA & 1980-2011 & $8-39$ & White + Nonwhite & $>80$ & 0.6 \\
\hline Toresdahl et al., 2014 [10] & USA & 2009-2011 & College & Black + White & 4.1 & 1.1 \\
\hline Roberts et al., 2013 [11] & Minnesota & 1993-2012 & $12-19$ & High school athletes & 1.7 & 0.2 \\
\hline
\end{tabular}


Table 2. Cont.

\begin{tabular}{|c|c|c|c|c|c|c|}
\hline Authors & Country & $\begin{array}{l}\text { Studied } \\
\text { Period }\end{array}$ & $\begin{array}{l}\text { Age } \\
\text { Years }\end{array}$ & Category & $\begin{array}{c}\text { Total } \\
\text { Million }\end{array}$ & $\begin{array}{c}\text { Incidence Rate } \\
\qquad / 100,000\end{array}$ \\
\hline Landry et al., 2017 [12] & Canada & 2009-2014 & $12-45$ & & 18.5 & 0.8 \\
\hline Holst et al., 2010 [8] & Denmark & $2000-2006$ & $12-35$ & White & 1.6 & 1.2 \\
\hline Marijon et al., 2011 [7] & France & $2005-2010$ & $10-35$ & White & 13.4 & 1.0 \\
\hline Bohm et al., 2016 [5] & Germany & $2012-2014$ & $10-79$ & & & $0.1-0.2$ \\
\hline Corrado et al., 1998 [13] & Italy & 1979-2004 & $12-35$ & White & 36.1 & 2.1 \\
\hline Steinvil et al., 2011 [14] & Israel & 1985-2009 & $10-40$ & & & 2.6 \\
\hline
\end{tabular}

\section{Differences between Sex, Ethnicity and Sports}

In Pacific Islanders, the incidence rate according to sex was seven times higher for males than for females [4]. For males, football is the most practiced sport, followed by volleyball, martial arts and rugby. For females, the most important sport is volleyball. These sports represent more than $50 \%$ of all sports practiced. They are mainly anaerobic and known to serve as a trigger for ventricular arrhythmias on underlying, predominantly silent, rheumatic heart disease. A specific aerobic sport called Va'a, namely sea canoeing, is widely practiced in Polynesia.

Pacific Island athletes [4], Afro-Caribbean [15], Asian [16], West-Asian [17] and South of Far East athletes [18] have heart specificities when compared to Caucasians.

Football, running, swimming gymnastics, rugby and tennis were also reported to have a higher incidence of SCD than other less popular sports [6].

\section{Causes of Sudden Cardiac Death}

In 842 athletes, Maron et al. [6] found that SCD was mainly due to hypertrophic cardiomyopathy (HCM) plus indeterminate left ventricular hypertrophy (LVH) considered as possible HCM (45\%), 3.5-fold more common among males than among females, as well as anomalous coronary artery (33\% of females vs. $17 \%$ of males), arrhythmogenic cardiomyopathy (ACM) (13\% of females vs. $4 \%$ of males) and myocarditis $(6 \%)$.

In Pacific Island Athletes, the main causes of SCD are severe valve lesions of rheumatoid origin identified in $25 \%$ of athletes [4].

\section{Prevention of Sudden Cardiac Death}

Cardiovascular prevention has a marked place in PPE for competitive sports. Specific attention is given to males and to communities such as Melanesians, Polynesians or AfroCaribbean groups $[4,6]$.

Scientific committees recommend a PPE program that encompasses family and personal history, physical examination and a systematic resting twelve-lead electrocardiogram (ECG) for competitive sports in subjects between 12 and 35 years. This ECG must be repeated every $2-3$ years [19].

For Pacific Island athletes, both ECG and echocardiography are recommended. Indeed, in the PPE of athletes, including systematic ECG screening, up to $3.9 \%$ of cardio-vascular abnormalities were found [4]. In school surveys using systematic echocardiographic screening, a high prevalence of $\mathrm{RDH}$ has been found ranging from 2.9 to $7.6 \%$ in asymptomatic school children, Melanesians and Polynesians across the developing countries Fiji, New Caledonia and New Zealand [20].

\section{Questionnaire and Physical Examination}

\subsection{Medical History Questionnaires}

For Pacific Islanders, specific attention is given to their history of ARF, an autoimmune disease that follows throat infection or reinfection with the bacterium Group A Streptococcus [21]. It is estimated that $60 \%$ of all those contracting ARF will develop RHD. Although 
RHD has almost disappeared from industrialized and wealthy countries, it remains the most frequent heart disease in children worldwide.

The questionnaire addresses family history, and the present and past complaints of the personal history. The short questionnaire of the AHA [22] of 14 items is recommended.

\subsection{Family History}

Family history focuses on (i) known RDH, valvular lesions, valve replacement surgery (ii) premature/unexpected SCD in at least one first degree relative before the age of 50, and (iii) inherited cardiac diseases like CM, Marfan syndrome, short or long QT syndrome, and severe arrhythmias. Any family history of SCD before the age of 35 years necessitates a cardiological referral to determine what further diagnostic testing is to be conducted because of the prevalent genetic transmission of HCM, long QT, ACM, Marfan Syndrome and related vascular disorders including familial biscupid aortic valve.

\subsection{Personal History}

Personal history focuses on previous ARF during childhood, repeated throat infections, iterative joint pain and on five determinant symptoms related to exercise: (i) syncope or near syncope, (ii) exertional chest pain, (iii) shortness of breath, (iv) palpitation, and (v) abnormal dyspnea or fatigue. The questionnaire also assesses previously known severe cardiovascular diseases. It assesses less severe cardiovascular diseases like cardiac murmur, arterial hypertension, smoking habits, recent infection, prescribed medication and results of previous systematic echocardiography.

\subsection{Physical Examination}

The physical examination focuses on abnormal cardiac area auscultation related to $\mathrm{RDH}$ such as heart murmur diastolic or systolic $>2 / 6$, fixed by respiration and reinforced after exercise, systolic click, irregular heart rhythm, and/or asymetric artery pulses especially beetwen the arms and legs (aorta coarctation), bilateral brachial blood pressure, musculoskeletal and ocular features suggestive of Marfan syndrome.

\section{Standard Twelve-Lead Resting ECG}

In Pacific Island athletes, the 2018 International Recommendations [23] are applicable: increased vagal tone and cardiac dimensions with bradycardia, first degree atrio-ventricular block, large QRS voltage, incomplete right bundle blanch block [18]. Early repolarization is present in about $50 \%$ of Pacific athletes, as in Afro-Caribbean athletes. Most of the TWIs located in the V2 to V4 leads are not associated with any CV disease [21].

In Pacific Island athletes, the uncommon ECG changes requiring further cardiac investigations are presented in Table 3.

Table 3. Twelve-lead ECG criteria requiring further cardiac investigations in Pacific Island athletes [4].

\begin{tabular}{|c|c|}
\hline Heart Frequency & Bradycardia $<30 \mathrm{bpm}$ or Pauses $\geq 3 \mathrm{~s}$ \\
\hline P wave & $\begin{array}{l}\text { In I and II amplitude }>2.5 \mathrm{~mm} \text { and/or duration }>120 \mathrm{~ms} \text { * } \\
\text { In V1-V2, }>1 \mathrm{~mm} \text { in depth, }>40 \mathrm{~ms} \text { in duration * } \\
\text { Atrial fibrillation, flutter, supraventricular tachycardia }\end{array}$ \\
\hline PR interval & $\begin{array}{l}\text { PR }<120 \mathrm{~ms} \text { and delta wave at the beginning of QRS } \\
\text { and sometimes inverted T waves = WPW. } \\
\text { Atrio-ventricular block } 1^{\circ} \geq 400 \mathrm{~ms} \\
\text { Mobitz II, } 2^{\circ} \text { block without Wenckebach phenomenon. } \\
\quad 3^{\circ} \text { complete AV block }\end{array}$ \\
\hline Q wave & $\begin{array}{c}\mathrm{Q} / \mathrm{R} \text { ratio } 25 \% \text { or }>40 \mathrm{~ms} \text { duration in } 2 \text { or more leads } \\
\text { except III and aVR }\end{array}$ \\
\hline
\end{tabular}


Table 3. Cont.

\begin{tabular}{|c|c|}
\hline Heart Frequency & Bradycardia $<30 \mathrm{bpm}$ or Pauses $\geq 3 \mathrm{~s}$ \\
\hline QRS complex & $\begin{array}{c}\text { Delta wave } \\
\text { LBBB }>120 \mathrm{~ms}, \\
\mathrm{RBBB}>120 \mathrm{~ms} * \\
\text { Any QRS }>140 \mathrm{~ms} \\
\text { Left and right axis deviation }<-30^{\circ}>120^{\circ} * \\
\mathrm{R} \text { wave in } \mathrm{V} 1>7 \mathrm{~mm} * \\
\mathrm{R} / \mathrm{S}>1 \text { in V1-V2 } * \mathrm{R} / \mathrm{S}<1 \text { in } \mathrm{V} 5-\mathrm{V} 6 * \\
\text { Brugada Type } 1 \\
\text { Epsilon wave }\end{array}$ \\
\hline ST segment & $\begin{array}{c}\text { Depression }>0.5 \mathrm{~mm} \text { in } 2 \text { or more contiguous leads } \\
\text { Depression }>1 \mathrm{~mm} \text { in any lead }\end{array}$ \\
\hline Inverted $\mathrm{T}$ wave & $\begin{array}{l}\geq 1 \mathrm{~mm} \text { in depth in } 2 \text { or more contiguous leads } \\
\text { Before puberty in any lead except III, VR, V1, V2, V3 } \\
\text { Post puberty and adult in any lead except III, VR, V1 } \\
\text { Except V2, if IRBBB } \\
\text { Except V2, V3 and V4 in Black athletes }\end{array}$ \\
\hline QTc & $\begin{array}{l}>470 \mathrm{~ms} \text { in male, }>480 \mathrm{~ms} \text { in female } \\
<340 \mathrm{~ms} \text { in any athlete }\end{array}$ \\
\hline Ventricular premature beat & $\begin{array}{l}\geq 2 \text { premature ventricular beats per } 10 \mathrm{~s} \text { tracing } \\
\text { Doubletss, triplets and non-sustained ventricular tachycardia }\end{array}$ \\
\hline
\end{tabular}

ECG: electrocardiogram, IRBBB: incomplete right bundle-branch block, LBBB: left bundle-branch block, QTc: corrected QT duration (Bazet formula), WPW: Wolff-Parkinson-White. * If isolated, asymptomatic and no family or personal history with no need for further investigation, if in association with 2 or more * criteria, further investigation is required [23].

\section{Echocardiography and Other Investigations}

In the case of Pacific Island athletes, the World Heart Foundation 2012 criteria [24] for echocardiographic diagnosis of definite or borderline RHD are applied. RHD predominantly affects the left-sided cardiac valves, $>95 \%$ of mitral lesions mainly regurgitations, $1 / 3$ being associated with aortic lesions causing regurgitation, stenosis, or mixed hemodynamic effects. Very few aortic lesions occur on their own [20].

In 2281 Pacific Island adolescents, a 4-fold increase in the incidence of the RDH was found in the 9 to 16 age group ( 1 to $4 \%$ ). Most of them were silent. A systematic echocardiography screening was thus recommended for children aged 9-10 and for adolescent Pacific Island athletes ( $16 \pm 1$ year). For master athletes, echocardiography should also be recommended at least once between the age of 30 and 40 [20].

Other investigations, like stress ECG are of major importance for detecting disappearance or worsening of resting arrhythmias and ECG abnormalities like $\mathrm{T}$ wave inversion. It must be pointed out that in some low-income Pacific Islands these investigations, although highly recommended, cannot always be performed either for economic reasons or the lack of sports cardiologists or specialized medical facilities.

\section{Results of Sports Pre-Participation Evaluation}

In Pacific Island athletes, Chatard et al. [4] found $0.8 \%$ of athletes at risk of an SCD with a cardio-vascular disease contraindicating competitive sport and 3.9\% presented a $\mathrm{CV}$ disease that needed a regular medical follow up. The major observation was the high prevalence $(1.5 \%)$ of silent valve diseases of rheumatoid origin almost four times higher than those reported in athletes of Western and Middle Eastern countries (Table 4). 
Table 4. Number of cardiac diseases found after athlete screening in 13 studies. M: male, Cat: athlete category, CI: contraindication to sports, MC: myocardiopathy, LVH: left ventricular hypertrophy, WPW: Wolff-Parkinson-White, QT: long QTc, VA: ventricular arrhythmia, AHT: arterial hypertension, Val: valvulopathy, IAC: interatrial communication, Brug: Brugada.

\begin{tabular}{|c|c|c|c|c|c|c|c|c|c|c|c|c|c|c|c|}
\hline Studies & $n$ & M\% & Cat & Ethny & Age & $\mathrm{CI}$ & MC & LVH & WPW & QT & VA & AHT & Val & IAC & Brug \\
\hline Corrado et al., 1998 [13] & 33,735 & 85 & A & Ita & 19 & 621 & 34 & $6 \bullet$ & 44 & 37 & 121 & 168 & 133 & & \\
\hline Fuller et al., 1997 [25] & 5615 & 60 & HS & Ca? & $13-19$ & 22 & 0 & $3 *$ & 1 & 0 & 15 & 20 & 43 & 0 & 0 \\
\hline Basavarajaiah et al., 2008 [15] & 3500 & 75 & $\mathrm{E}$ & $98 \% \mathrm{Ca}$ & 20.5 & 15 & 0 & $53^{\circ}$ & 6 & 9 & 0 & 0 & 9 & 2 & 0 \\
\hline Papadakis et al., 2011 [26] & 2745 & 100 & A & $\begin{array}{l}66 \% \mathrm{Ca} \\
33 \% \mathrm{Ba}\end{array}$ & $14-35$ & 12 & 4 & $112^{\circ}$ & 4 & 3 & 0 & 22 & 5 & 5 & 1 \\
\hline Chatard et al., 2019 [4] & 2281 & 69 & $\mathrm{E}$ & $\begin{array}{l}31 \% \text { Mel } \\
29 \% \text { Poly } \\
21 \% \text { Cau } \\
20 \% \text { Met }\end{array}$ & $10-40$ & 18 & 8 & - & 6 & 5 & 8 & 6 & 35 & 8 & 0 \\
\hline Price et al., 2014 [27] & 2017 & 71 & S & $\begin{array}{l}34 \% \mathrm{Ca} \\
31 \% \mathrm{Ba}\end{array}$ & $14-18$ & 5 & 1 & $1 \bullet$ & 4 & 1 & 0 & 0 & 3 & 0 & 0 \\
\hline Magalski et al., 2008 [28] & 1959 & 100 & $\mathrm{EF}$ & $\begin{array}{l}67 \% \mathrm{Ba} \\
31 \% \mathrm{Ca}\end{array}$ & 23 & 0 & 0 & $6 \bullet$ & 0 & 0 & 0 & $?$ & 0 & 0 & 0 \\
\hline Hevia et al., 2012 [29] & 1220 & 96 & S & $\mathrm{Ca} ?$ & 23 & 2 & 2 & $8 \bullet$ & 4 & 0 & 4 & 0 & 0 & 0 & 0 \\
\hline Wilson et al., 2012 [17] & 1220 & 100 & $\mathrm{AP}$ & $\begin{array}{l}66 \% \mathrm{Wa} \\
25 \% \mathrm{Ba}\end{array}$ & 22.6 & 7 & 4 & $13 \bullet$ & 2 & 1 & 1 & 10 & 2 & 1 & 0 \\
\hline Wilson et al., 2008 [30] & 1074 & 100 & $\mathrm{~J}$ & Ca? & 15.8 & 9 & 1 & 0 & 4 & 3 & 1 & $?$ & $?$ & $?$ & 0 \\
\hline Menafoglio et al., 2013 [31] & 1070 & 75 & A & $98 \% \mathrm{Ca}$ & 19.7 & 4 & 0 & 0 & 3 & 1 & 0 & 1 & 5 & 0 & 0 \\
\hline Mayer et al., 2012 [32] & 733 & 57 & ES & $\mathrm{Ca} ?$ & 12.3 & 4 & 1 & 0 & 3 & 0 & 0 & 0 & 10 & 3 & 0 \\
\hline Baggish et al., 2010 [33] & 508 & 61 & S & $\begin{array}{l}68 \% \mathrm{Ca} \\
10 \% \mathrm{Ba}\end{array}$ & 19 & 3 & 2 & $2 *$ & 0 & 0 & 0 & 0 & 7 & 0 & 0 \\
\hline Total & 57,677 & - & - & - & - & 722 & 57 & 204 & 81 & 60 & 150 & 227 & 252 & - & - \\
\hline Mean percentage & & 82 & - & - & 19.4 & 1.3 & 1.0 & 0.35 & 0.14 & 0.10 & 0.26 & 0.40 & 0.43 & - & - \\
\hline
\end{tabular}

A: amateur, AP: amateur and professional, E: elite, ES, elite school of sports, EF: elite football players, HS: high school, J: junior, S: student athletes. Ba: Black, Ca: Caucasian, Ita: Italian, Wa: West-asian, Arabic, Left ventricular thickness: ${ }^{*} \geq 11 \mathrm{~mm},{ }^{\circ} \geq 12 \mathrm{~mm}, \bullet \geq 13 \mathrm{~mm}$.

Another observation concerning the Pacific Islanders was their high HCM prevalence (2.6/1000 athletes). Only 50\% were symptomatic, while all had an abnormal ECG confirming the value of an ECG examination [18,34].

In Pacific Island athletes, the HCM prevalence was close to the 3.2/1000 athletes found by Wilson et al. [17]. In these two studies, Black athletes, Melanesian and Afro-Caribbean athletes, were highly represented.

Wolff-Parkinson-White, inter-auricular or ventricular communications, long QT syndrome, ventricular arrhythmia and high blood pressure were the other most prevalent abnormalities found, confirming previous PPE studies (Table 4).

In the future, there is clearly a need for follow up and research in professional/high level athletes, undergoing structural treatment of rheumatic heart disease. Eligibility can be given as soon as the follow up of the valve repair, valvuloplasty or valve replacement is successfully performed, confirmed by echocardiography and stress ECG.

\section{Conclusions}

In Pacific Island athletes, there is a significant risk of SCD, especially in male adolescents, young adults and Black athletes. Most instances of SCD are due to silent arrhythmogenic cardiovascular diseases.

A systematic twelve-lead ECG would save lives. Indeed, Melanesians, of Black origin, presented with frequent TWIs in V2-V4 similar to those described in Afro-Caribbean athletes. Most of the other TWIs were associated with cardiomyopathies.

The high prevalence of RHD also confirms the importance of including a systematic echocardiography in PPE for Pacific Island athletes whatever their age.

Funding: This research was funded by a grant from Fond Pacific and the Ministère des Affaires Etrangères et du Développement International, AFD CTZ $105601 \mathrm{~T}$ and a grant of Philips industry. 
Acknowledgments: The authors would like to thank (i) James Pryce who has extensive experience revising medical articles for reviewing the English manuscript (ii) François Carré and Florian Espinosa for their help in the whole Pacific Islands studies.

Conflicts of Interest: The author has no conflict of interest to declare that are directly relevant to the content of this review.

\section{References}

1. Harmon, K.G.; Asif, I.M.; Klossner, D.; Drezner, J.A. Incidence of sudden cardiac death in National Collegiate Athletic Association athletes. Circulation 2011, 123, 1594-1600. [CrossRef] [PubMed]

2. Finocchiaro, G.; Papadakis, M.; Robertus, J.L.; Dhutia, H.; Steriotis, A.K.; Tome, M.; Mellor, G.; Merghani, A.; Malhotra, A.; Behr, E.; et al. Etiology of Sudden Death in Sports: Insights from a United Kingdom Regional Registry. J. Am. Coll. Cardiol. 2016, 67, 2108-2115. [CrossRef]

3. Prakash, K.; Sharma, S. The Electrocardiogram in Highly Trained Athletes. Clin. Sports Med. 2015, 34, 419-431. [CrossRef]

4. Chatard, J.C.; Espinosa, F.; Donnadieu, R.; Grangeon, J.P.; Sabot, J.M.; Guivarch, C.; Dacquin, R.; Raby, F.X.; Papouin, G.; Viali, S.; et al. Pre-participation cardiovascular evaluation in Pacific Island athletes. Int. J. Cardiol. 2019, 278, 273-279. [CrossRef] [PubMed]

5. Bohm, P.; Scharhag, J.; Meyer, T. Data from a nationwide registry on sports-related sudden cardiac deaths in Germany. Eur. J. Prev. Cardiol. 2016, 23, 649-656. [CrossRef] [PubMed]

6. Maron, B.J.; Haas, T.S.; Ahluwalia, A.; Murphy, C.J.; Garberich, R.F. Demographics and Epidemiology of Sudden Deaths in Young Competitive Athletes: From the United States National Registry. Am. J. Med. 2016, 129, 1170-1177. [CrossRef] [PubMed]

7. Marijon, E.; Tafflet, M.; Celermajer, D.S.; Dumas, F.; Perier, M.C.; Mustafic, H.; Toussaint, J.F.; Desnos, M.; Rieu, M.; Benameur, N.; et al. Sports-related sudden death in the general population. Circulation 2011, 124, 672-681. [CrossRef]

8. Holst, A.G.; Winkel, B.G.; Theilade, J.; Kristensen, I.B.; Thomsen, J.L.; Ottesen, G.L.; Svendsen, J.H.; Haunso, S.; Prescott, E.; Tfelt-Hansen, J. Incidence and etiology of sports-related sudden cardiac death in Denmark-Implications for preparticipation screening. Heart Rhythm. 2010, 7, 1365-1371. [CrossRef] [PubMed]

9. Corrado, D.; McKenna, W.J. Appropriate interpretation of the athlet's electrocardiogram saves lives as well as money. Eur. Heart J. 2007, 28, 1920-1922. [CrossRef]

10. Toresdahl, B.G.; Rao, A.L.; Harmon, K.G.; Drezner, J.A. Incidence of sudden cardiac arrest in high school student athletes on school campus. Heart Rhythm. 2014, 11, 1190-1194. [CrossRef]

11. Roberts, W.O.; Stovitz, S.D. Incidence of sudden cardiac death in Minnesota high school athletes $1993-2012$ screened with a standardized pre-participation evaluation. J. Am. Coll. Cardiol. 2013, 62, 1298-1301. [CrossRef] [PubMed]

12. Landry, C.H.; Allan, K.S.; Connelly, K.A.; Cunningham, K.; Morrison, L.J.; Dorian, P. Sudden Cardiac Arrest during Participation in Competitive Sports. N. Engl. J. Med. 2017, 377, 1943-1953. [CrossRef] [PubMed]

13. Corrado, D.; Basso, C.; Schiavon, M.; Thiene, G. Screening for hypertrophic cardiomyopathy in young athletes. N. Engl. J. Med. 1998, 339, 364-369. [CrossRef] [PubMed]

14. Steinvil, A.; Chundadze, T.; Zeltser, D.; Rogowski, O.; Halkin, A.; Galily, Y.; Perluk, H.; Viskin, S. Mandatory electrocardiographic screening of athletes to reduce their risk for sudden death proven fact or wishful thinking? J. Am. Coll. Cardiol. 2011, 57, 1291-1296. [CrossRef] [PubMed]

15. Basavarajaiah, S.; Boraita, A.; Whyte, G.; Wilson, M.; Carby, L.; Shah, A.; Sharma, S. Ethnic differences in left ventricular remodeling in highly-trained athletes relevance to differentiating physiologic left ventricular hypertrophy from hypertrophic cardiomyopathy. J. Am. Coll. Cardiol. 2008, 51, 2256-2262. [CrossRef]

16. Kervio, G.; Pelliccia, A.; Nagashima, J.; Wilson, M.G.; Gauthier, J.; Murayama, M.; Uzan, L.; Ville, N.; Carre, F. Alterations in echocardiographic and electrocardiographic features in Japanese professional soccer players: Comparison to African-Caucasian ethnicities. Eur. J. Prev. Cardiol. 2013, 20, 880-888. [CrossRef]

17. Wilson, M.G.; Chatard, J.C.; Carre, F.; Hamilton, B.; Whyte, G.P.; Sharma, S.; Chalabi, H. Prevalence of electrocardiographic abnormalities in West-Asian and African male athletes. Brit. J. Sports Med. 2012, 46, 341-347. [CrossRef]

18. Ozo, U.; Sharma, S. The Impact of Ethnicity on Cardiac Adaptation. Eur. Cardiol. 2020, 15, e61. [CrossRef]

19. Chatard, J.C.; Mujika, I.; Goiriena, J.J.; Carre, F. Screening young athletes for prevention of sudden cardiac death: Practical recommendations for sports physicians. Scand. J. Med. Sci. Sports 2016, 26, 362-374. [CrossRef]

20. Chatard, J.C.; Dubois, T.; Espinosa, F.; Kamblock, J.; Ledos, P.H.; Tarpinian, E.; Da Costa, A. Screening Rheumatic Heart Disease in 1530 New Caledonian Adolescents. J. Am. Heart Assoc. 2020, 9, e015017. [CrossRef]

21. Carapetis, J.R.; McDonald, M.; Wilson, N.J. Acute rheumatic fever. Lancet 2005, 366, 155-168. [CrossRef]

22. Maron, B.J.; Thompson, P.D.; Ackerman, M.J.; Balady, G.; Berger, S.; Cohen, D.; Dimeff, R.; Douglas, P.S.; Glover, D.W.; Hutter, A.M., Jr.; et al. Recommendations and considerations related to preparticipation screening for cardiovascular abnormalities in competitive athletes: 2007 update: A scientific statement from the American Heart Association Council on Nutrition, Physical Activity, and Metabolism: Endorsed by the American College of Cardiology Foundation. Circulation 2007, 115, 1643-1655. [PubMed]

23. Sharma, S.; Drezner, J.A.; Baggish, A.; Papadakis, M.; Wilson, M.G.; Prutkin, J.M.; La Gerche, A.; Ackerman, M.J.; Borjesson, M.; Salerno, J.C.; et al. International recommendations for electrocardiographic interpretation in athletes. Eur. Heart J. 2018, 39, 1466-1480. [CrossRef] [PubMed] 
24. Remenyi, B.; Wilson, N.; Steer, A.; Ferreira, B.; Kado, J.; Kumar, K.; Lawrenson, J.; Maguire, G.; Marijon, E.; Mirabel, M.; et al. World Heart Federation criteria for echocardiographic diagnosis of rheumatic heart diseas-An evidence-based guideline. Nat. Rev. Cardiol. 2012, 9, 297-309. [CrossRef]

25. Fuller, C.M.; McNulty, C.M.; Spring, D.A.; Arger, K.M.; Bruce, S.S.; Chryssos, B.E.; Drummer, E.M.; Kelley, F.P.; Newmark, M.J.; Whipple, G.H. Prospective screening of 5615 high school athletes for risk of sudden cardiac death. Med. Sci. Sports Exerc. 1997, 29, 1131-1138. [CrossRef]

26. Papadakis, M.; Carre, F.; Kervio, G.; Rawlins, J.; Panoulas, V.F.; Chandra, N.; Basavarajaiah, S.; Carby, L.; Fonseca, T.; Sharma, S. The prevalence, distribution, and clinical outcomes of electrocardiographic repolarization patterns in male athletes of African/Afro-Caribbean origin. Eur. Heart J. 2011, 32, 2304-2313. [CrossRef]

27. Price, D.E.; McWilliams, A.; Asif, I.M.; Martin, A.; Elliott, S.D.; Dulin, M.; Drezner, J.A. Electrocardiography-inclusive screening strategies for detection of cardiovascular abnormalities in high school athletes. Heart Rhythm. 2014, 11, 442-449. [CrossRef]

28. Magalski, A.; Maron, B.J.; Main, M.L.; McCoy, M.; Florez, A.; Reid, K.J.; Epps, H.W.; Bates, J.; Browne, J.E. Relation of race to electrocardiographic patterns in elite American football players. J. Am. Coll. Cardiol. 2008, 51, 2250-2255. [CrossRef]

29. Hevia, A.C.; Fernandez, M.M.; Palacio, J.M.; Martin, E.H.; Castro, M.G.; Reguero, J.J. ECG as a part of the preparticipation screening programme: An old and still present international dilemma. Brit. J. Sports Med. 2011, 45, 776-779. [CrossRef]

30. Wilson, M.G.; Basavarajaiah, S.; Whyte, G.P.; Cox, S.; Loosemore, M.; Sharma, S. Efficacy of personal symptom and family history questionnaires when screening for inherited cardiac pathologies: The role of electrocardiography. Brit. J. Sports Med. 2008, 42, 207-211. [CrossRef]

31. Menafoglio, A.; Di Valentino, M.; Segatto, J.M.; Siragusa, P.; Pezzoli, R.; Maggi, M.; Romano, G.A.; Moschovitis, G.; Wilhelm, M.; Gallino, A. Costs and yield of a 15-month preparticipation cardiovascular examination with ECG in 1070 young athletes in Switzerland: Implications for routine ECG screening. Brit. J. Sports Med. 2014, 48, 1157-1161. [CrossRef] [PubMed]

32. Mayer, F.; Bonaventura, K.; Cassel, M.; Mueller, S.; Weber, J.; Scharhag-Rosenberger, F.; Carlsohn, A.; Baur, H.; Scharhag, J. Medical results of preparticipation examination in adolescent athletes. Brit. J. Sports Med. 2012, 46, 524-530. [CrossRef] [PubMed]

33. Baggish, A.L.; Hutter, A.M., Jr.; Wang, F.; Yared, K.; Weiner, R.B.; Kupperman, E.; Picard, M.H.; Wood, M.J. Cardiovascular screening in college athletes with and without electrocardiography: A cross-sectional study. Ann. Intern. Med. 2010, 152, 269-275. [CrossRef]

34. Asif, I.M.; Harmon, K.G. Incidence and Etiology of Sudden Cardiac Death: New Updates for Athletic Departments. Sports Health 2017, 9, 268-279. [CrossRef] [PubMed] 